ISSN 1678-3921

Journal homepage: www.embrapa.br/pab

For manuscript submission and journal contents, access: www.scielo.br/pab
Francielle de Oliveira Marx ${ }^{(1)}$ (iD, Josiane Carla Panisson ${ }^{(1)}$ (ID), Leopoldo Malcorra de Almeida(1) (iD, Everton Luís Krabbe ${ }^{(2)}$ (iD, Alex Maiorka ${ }^{(1)}$ (iD) and Simone Gisele de Oliveira ${ }^{(1 凶)}$ (iD

(1) Universidade Federal do Paraná, Rua dos Funcionários, № 1.540, Juvevê, CEP 80035 050 Curitiba, PR, Brazil. E-mail: franciellemarx@hotmail.com, josipanisson@gmail.com almeidamleopoldo@gmail.com amaiorka@ufpr.br, sgoliveira@ufpr.br

(2) Embrapa Suínos e Aves, Rodovia BR-153, $\mathrm{Km}$ 110, Distrito de Tamanduá, Caixa Postal 321, CEP 89715-899 Concórdia, SC, Brazil. E-mail: everton.krabbe@embrapa.br

$\bowtie$ Corresponding author

Received

June 01, 2020

Accepted

December 07,2020

How to cite

MARX, F. de O.; PANISSON, J.C.; ALMEIDA, L.M . de; KRABBE, E.L.; MAIORKA, A.; OLIVEIRA, S.G. de. Performance of broilers fed mash or pelleted diets containing different soybean meal particle sizes. Pesquisa Agropecuária Brasileira, v.56, e02047, 2021 DOI: https://doi.org/10.1590/S1678-3921. pab2021.v56.02047.

\section{Performance of broilers fed mash or pelleted diets containing different soybean meal particle sizes}

\begin{abstract}
The objective of this work was to evaluate the effect of different soybean meal particle sizes in pelleted or mash diets on broiler performance. A total of 1,440 male Cobb500 broilers, with 1 to 35 days of age, were evaluated. The experimental design was completely randomized, in a $2 \times 4$ factorial arrangement, consisting of two feed physical forms and four soybean meal particle sizes $(625,775,1,053$, and $1,406 \mu \mathrm{m})$, totaling eight treatments, with nine replicates of 20 birds each. Feed intake, weight gain, and feed conversion ratio were evaluated. There was a significant interaction between diet physical form and soybean meal particle size. From 1 to 21 days of age, the lowest feed intake and weight gain values were obtained with the mash diet containing 1,406 $\mu \mathrm{m}$ soybean meal particle size. From 1 to 35 days of age, the greatest weight gain is achieved when broilers are fed the pelleted diet with $1,406 \mu \mathrm{m}$ soybean meal particle size.
\end{abstract}

Index terms: Glycine max, Cobb500, feed conversion ratio, feed intake.

\section{Desempenho de frangos de corte alimentados com dietas fareladas e peletizadas contendo diferentes tamanhos de partícula de farelo de soja}

Resumo - O objetivo deste trabalho foi avaliar o efeito de diferentes tamanhos de partícula de farelo de soja, em dietas fareladas e peletizadas, no desempenho de frangos de corte. Foram avaliados 1.440 pintos de corte machos da linhagem Cobb500, com 1 a 35 dias de idade. O delineamento experimental foi inteiramente casualizado, em arranjo fatorial $2 \times 4$, com duas formas físicas da dieta e quatro granulometrias de farelo de soja $(625,775$, 1.053 e $1.406 \mu \mathrm{m}$ ), tendo totalizado oito tratamentos, com nove repetições com 20 aves cada uma. Foram avaliados consumo de ração, ganho de peso e conversão alimentar. Houve interação significativa entre as formas físicas das dietas e o tamanho das partículas do farelo de soja. De 1 a 21 dias de idade, os menores valores de consumo de ração e ganho de peso foram obtidos com a dieta farelada contendo partículas do farelo de soja de $1.406 \mu \mathrm{m}$. Já de $1 \mathrm{a}$ 35 dias de idade, o maior ganho de peso é alcançado quando os frangos são alimentados com dietas peletizadas com tamanho de particula do farelo de soja de $1.406 \mu \mathrm{m}$.

Termos para indexação: Glycine max, Cobb500, taxa de conversão alimentar, consumo de ração. 


\section{Introduction}

Soybean [Glycine max (L.) Merr.] meal (SBM) is typically the main protein feedstuff included in livestock diets (Félix et al., 2010; Oliveira et al., 2020). After subjected to an adequate heat treatment, SBM has a high crude protein content, as well as a high digestible energy and low fiber contents (Félix et al., 2010).

In general, SBM makes up 30\% of broiler diets (Duarte \& Junqueira, 2013). However, broiler performance is strongly influenced by feed particle size and physical form (Shabani et al., 2015). Feed particle size affects feed manufacturing, besides feed intake, diet digestibility, and, consequently, broiler performance (Teixeira Netto et al., 2019). Studies have shown that broiler live performance is improved by the supply of coarser feed particles, compared with that of finer ones (Pacheco et al., 2013; Lv et al., 2015). However, age and digestive tract development stage should also be considered when evaluating broiler response to feed particle size (Kheravii et al., 2018).

Regarding physical forms, the main ones are mash and pellet. For mash feeds, the ingredients are grinded and homogenously mixed, whereas, for pelleted feeds, the feed mash is subjected to a thermal-mechanical process combining high temperature, humidity, and pressure (Amerah et al., 2011; Santos et al., 2020). One of the greatest benefits of feeding broilers with pelleted diets is the increase in feed intake and consequent better live performance (Massuquetto et al., 2020). Abdollahi et al. (2011) reported a 14\% increase in the feed intake of starter broilers fed pelleted diets, compared with those fed mash diets.

Several authors have investigated corn (Zea mays L.) particle sizes in poultry feeds (Chewning et al., 2012; Naderinejad et al., 2016; Kheravii et al., 2017). However, although SBM is typically the main protein source in poultry diets, only a few studies (Kilburn \& Edwards, 2004; Pacheco et al., 2013) have aimed to determine the adequate SBM particle size for broilers according to rearing phase.

The objective of this work was to evaluate the effect of different soybean meal particle sizes in pelleted or mash diets on broiler performance.

\section{Materials and Methods}

The research was approved by the ethics committee on animal use of the Agricultural Sciences Sector of Universidade Federal do Paraná, under protocol number 073/2015. The experiment was conducted throughout 2016, in the municipality of Curitiba, in

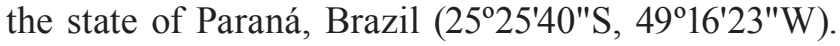
A total of 1,440 Cobb500 (Cobb-Vantress Brasil Ltda., Guapiaçu, SP, Brazil) male broiler chickens were used, aged from 1 to 35 days. The birds were housed in a masonry shed divided into 72 pens, measuring $2.06 \mathrm{~m}^{2}$ each (20 birds per pen). Each pen was equipped with a tube feeder, nipple drinkers, and a brooder; the floor was covered with wood-shavings litter. Feed and water were offered ad libitum. Continuous lighting was provided during the first 24 hours, after which the number of hours of light was gradually reduced according to the management manual of the broiler breeding company (Cobb-Vantress, 2013). Environmental temperature was maintained at $32^{\circ} \mathrm{C}$ on the first day and then gradually reduced to approximately $21^{\circ} \mathrm{C}$ on the thirty-fifth day.

The experimental design was completely randomized, in a $2 \times 4$ factorial arrangement, consisting of two feed physical forms (mash or pelleted) and of four SBM particle sizes $(625,775,1,053$, and 1,406 $\mu \mathrm{m})$, totaling eight treatments, with nine replicates of 20 birds each.

The different SBM particle sizes were obtained by using sieves with different hole sizes of $3,4,5$, and $6 \mathrm{~mm}$, during grinding in a hammer mill. Geometric mean diameter (GMD, $\mu \mathrm{m})$ and geometric standard deviation (GSD) of corn and SBM were determined according to the methodology of Zanotto \& Bellaver (1996). Initially, a $500 \mathrm{~g}$ sample was dried in a forced-air ventilation oven at $105^{\circ} \mathrm{C}$ for 24 hours, removed from the oven, allowed to reach environmental temperature, and weighed. Then, the sample was placed in the VP-01 electromagnetic sieve shaker (Bertel Ind. Metalúrgica Ltda., Caieiras, SP, Brazil) with six wire-mesh sieves, using known weights, according to standards 5, 10, 16, 30, 50, and 100 of Associação Brasileira de Normas Técnicas (ABNT) (Zanotto \& Bellaver, 1996), and finally shaken for $10 \mathrm{~min}$ with the rheostat set at 8 . After the shaking process was concluded, the weight of each sieve and its content were determined and recorded. Samples were analyzed in duplicate. Weights were entered in the Granucalc software (Dalmédico et al., 2013), which generated a report with the calculated GMD and GSD values of each sample. 
Corn particle size was maintained constant in all diets, and the values found for GMD and GSD were $1,168 \mu \mathrm{m}$ and 1.97 , respectively. For SBM ground with the sieve mesh sizes of $3,4,5$, and $6 \mathrm{~mm}$, the values obtained for GMD were $625,775,1,053$, and 1,406 $\mu \mathrm{m}$ and for GSD, 1.76, 1.72, 1.81, and 1.94, respectively.

The experimental diets were based on corn and SBM and formulated according to the recommendations of Brazilian tables for poultry and swine (Rostagno et al., 2011), as shown in Table 1. Mash diets were pelleted in the Junior C40 steam pellet mill (Koppers Company, Inc., Pittsburgh, PA, USA). Broilers were fed starter diets from 1 to 21 days of age and grower diets from 22 to 35 days; the pelleted starter diet was crumbled after cooling.

Live performance parameters were evaluated from 1 to 21 (starter period) and from 1 to 35 (total period) days of age. During each experimental period, feed offer and leftovers were weighed weekly and recorded in spreadsheets to obtain the average feed intake (AFI) per period. Birds were weighed on days 1, 21, and 35 to determine average weight gain (AWG) and feed conversion ratio (FCR).

Data were tested for normality by Shapiro-Wilk's test, and, when this assumption was accepted, data were subjected to the analysis of variance using the GLM procedure of the SAS statistical package (SAS Institute Inc., Cary, NC, USA), according to the experimental design previously described. When significant interactions were detected, results were unfolded and compared by Tukey's test, at $5 \%$ probability. Linear and quadratic responses for SBM particle size were assessed using orthogonal polynomial contrast statements, and the statistical significance was based on $5 \%$ probability.

\section{Results and Discussion}

In the starter period, significant interactions were detected between feed physical form and SBM particle size for AFI, AWG, and FCR $(p<0.05)$. In the total experimental period, similar results were observed for AFI and AWG, but FCR was influenced only by SBM particle size (Table 2).

During the starter period, when mash diets were offered, birds fed 1,406 $\mu \mathrm{m}$ SBM particle size showed a lower AFI than those fed $625 \mu \mathrm{m}$ SBM (Table 2). However, among pelleted diets, the SBM particle size of $1,406 \mu \mathrm{m}$ promoted a higher AFI than that of $775 \mu \mathrm{m}$. It is possible that the $1,406 \mu \mathrm{m}$ SBM particle size in mash diets was excessively large for broilers of the evaluated age, decreasing AFI. According to Moran Jr. (1982), broilers are not able to apprehend feed particles larger than their beaks, as confirmed by López \& Baião (2002), who concluded that broilers select the most suitable feed particle sizes during each production stage. In this line, Jacobs et al. (2010) found

Table 1. Ingredients and nutritional composition of the experimental diets fed to Cobb500 broilers from 1 to 21 and from 1 to 35 days of age.

\begin{tabular}{|c|c|c|}
\hline \multirow{2}{*}{$\begin{array}{l}\text { Ingredients } \\
(\%)\end{array}$} & \multicolumn{2}{|c|}{ Diets } \\
\hline & Starter & Grower \\
\hline Corn & 54.89 & 57.30 \\
\hline Soybean meal 45\% & 37.08 & 34.95 \\
\hline Soybean oil & 2.73 & 4.24 \\
\hline Dicalcium phosphate & 1.75 & 1.23 \\
\hline Limestone & 0.85 & 0.93 \\
\hline Salt & 0.48 & 0.46 \\
\hline DL-methionine & 0.32 & 0.24 \\
\hline L-lysine $\mathrm{HCl}$ & 0.25 & 0.20 \\
\hline Mycotoxin adsorbent & 0.25 & 0.19 \\
\hline L-threonine & 0.13 & 0.08 \\
\hline Vitamin premix $^{(1)}$ & 0.12 & 0.07 \\
\hline Choline chloride & 0.10 & 0.05 \\
\hline Mineral premix ${ }^{(2)}$ & 0.05 & 0.05 \\
\hline $\mathrm{BHT}^{(3)}$ & 0.01 & 0.01 \\
\hline \multicolumn{3}{|l|}{ Calculated nutritional levels (\%) } \\
\hline Crude protein & 21.12 & 20.11 \\
\hline Ether extract & 5.41 & 6.87 \\
\hline Crude fiber & 2.93 & 2.84 \\
\hline Ashes & 2.91 & 2.81 \\
\hline Calcium & 0.85 & 0.75 \\
\hline Available phosphorus & 0.45 & 0.35 \\
\hline Sodium & 0.20 & 0.19 \\
\hline Chlorine & 0.34 & 0.32 \\
\hline Digestible lysine & 1.20 & 1.10 \\
\hline Digestible methionine & 0.59 & 0.50 \\
\hline Methionine + cysteine & 0.90 & 0.80 \\
\hline Digestible threonine & 0.80 & 0.72 \\
\hline Digestible tryptophan & 0.23 & 0.22 \\
\hline Metabolizable energy $\left(\mathrm{kcal} \mathrm{kg}^{-1}\right)$ & 2,980 & 3,100 \\
\hline
\end{tabular}

(1)Supplementation per kilogram of diet: 15,000 IU vitamin A, 5,000 IU vitamin D3, $100 \mathrm{mg}$ vitamin E, $5 \mathrm{mg}$ vitamin $\mathrm{K}, 3 \mathrm{mg}$ folic acid, $75 \mathrm{mg}$ nicotinic acid, $25 \mathrm{mg}$ pantothenic acid, $8 \mathrm{mg}$ riboflavin, $5 \mathrm{mg}$ thiamin, $7 \mathrm{mg}$ pyridoxine, $300 \mu \mathrm{g}$ biotin, $400 \mathrm{mg}$ choline, and $20 \mu \mathrm{g}$ vitamin B12. ${ }^{(2)}$ Concentration per kilogram of feed: $2 \mathrm{mg}$ iodine, $200 \mathrm{mg}$ selenium, $20 \mathrm{mg}$ copper, $50 \mathrm{mg}$ iron, $120 \mathrm{mg}$ manganese, and $100 \mathrm{mg}$ zinc. ${ }^{(3)} \mathrm{BHT}$, butylated hydroxytoluene. 
that corn particles larger than $1,387 \mu \mathrm{m}$ compromised the performance of 1- to 21-day-old broilers. When comparing SBM particle sizes between physical forms, the 1,406 $\mu \mathrm{m}$ SBM particle size in the pelleted diet resulted in a higher AFI (Table 2). However, there were no differences in AFI between mash and pelleted diets regarding the other evaluated particle sizes.

In the period of 1 to 21 days, the mash diet containing $1,406 \mu \mathrm{m}$ SBM particle size resulted in a lower AWG than that with 1,053 $\mu \mathrm{m} \mathrm{SBM}$ (Table 2). This low AWG may be attributed to the low feed intake observed and to the fact that the gizzard of young broilers is still not fully developed and, therefore, has a limited capacity to grind coarse particles (Kheravii et al., 2018).

However, when pelleted diets were fed, the coarsest SBM particle size, i.e., 1,406 $\mu \mathrm{m}$, promoted the highest AWG, indicating that the pelletizing process has a positive influence on the assessed performance parameters, specifically on AFI and AWG(Massuquetto et al., 2019). For FCR, although an interaction between diet physical form and SBM particle size was detected, the unfolding of the interaction by Tukey's test did not show any significant effects of either factor on this parameter (Table 2).

During the total experimental period, no differences in AFI were observed among the evaluated SBM particle sizes when broilers were fed mash or pelleted diets (Table 2). However, when comparing feed physical forms, a higher AFI was obtained with the $1,406 \mu \mathrm{m}$ SBM particle size in the pelleted diet, while no significant differences were detected when the other particle sizes were compared between mash and pelleted diets.

The better AWG results obtained with the pelleted diet may be attributed to several benefits of the feed pelleting process. It has been reported that pelleted diets facilitate the apprehension of feed particles by birds, resulting in a higher feed intake (McKinney \& Teeter, 2004). Pelleting also hinders the selection of feed particles, causes less feed waste, decreases the segregation and microbial load of feeds, increases the amount of dietary energy available for production as less time is required for the intake of pelleted feeds, and increases the digestibility of dietary fractions, such as

Table 2. Performance parameters of 1- to 35-day-old Cobb500 broilers fed mash or pelleted diets with different soybean (Glycine max) meal particle sizes ${ }^{(1)}$.

\begin{tabular}{|c|c|c|c|c|c|c|c|c|c|}
\hline \multirow{2}{*}{$\begin{array}{l}\text { Performance } \\
\text { parameters }\end{array}$} & \multirow{2}{*}{$\begin{array}{l}\text { Physical } \\
\text { form (B) }\end{array}$} & \multicolumn{4}{|c|}{ Geometric mean diameter - GMD $(\mathrm{A})(\mu \mathrm{m})$} & \multirow[t]{2}{*}{ SEM } & \multicolumn{3}{|c|}{ p-value } \\
\hline & & 625 & 775 & 1,053 & 1,406 & & (A) & (B) & $\mathrm{AxB}$ \\
\hline \multicolumn{10}{|c|}{ Age (1 to 21 days) } \\
\hline \multirow{2}{*}{$\begin{array}{l}\text { Average feed } \\
\text { intake - AFI (g) }\end{array}$} & Mash & $1,142 \mathrm{Aa}$ & $1,115 \mathrm{Aab}$ & $1,122 \mathrm{Aab}$ & $1,065 \mathrm{Bb}$ & \multirow{2}{*}{0.016} & \multirow{2}{*}{0.581} & \multirow{2}{*}{0.001} & \multirow{2}{*}{0.001} \\
\hline & Pelleted & $1,138 \mathrm{Aab}$ & $1,119 \mathrm{Ab}$ & $1,151 \mathrm{Aab}$ & $1,195 \mathrm{Aa}$ & & & & \\
\hline \multirow{2}{*}{$\begin{array}{l}\text { Average weight } \\
\text { gain - AWG (g) }\end{array}$} & Mash & 797.0Aab & 803.0Aab & 818.0Aa & $760.0 \mathrm{Bb}$ & \multirow{2}{*}{0.012} & \multirow{2}{*}{0.179} & \multirow{2}{*}{0.001} & \multirow{2}{*}{0.001} \\
\hline & Pelleted & $834.0 \mathrm{Ab}$ & $799.0 \mathrm{Ab}$ & $824.0 \mathrm{Ab}$ & 891.0Aa & & & & \\
\hline \multirow{2}{*}{$\begin{array}{l}\text { Feed conversion } \\
\text { rate }- \text { FCR }\end{array}$} & Mash & $1.436 \mathrm{Aa}$ & $1.390 \mathrm{Aa}$ & $1.371 \mathrm{Aa}$ & $1.403 \mathrm{Aa}$ & \multirow{2}{*}{0.018} & \multirow{2}{*}{0.339} & \multirow{2}{*}{0.085} & \multirow{2}{*}{0.017} \\
\hline & Pelleted & $1.365 \mathrm{Aa}$ & $1.402 \mathrm{Aa}$ & $1.398 \mathrm{Aa}$ & $1.343 \mathrm{Aa}$ & & & & \\
\hline \multicolumn{10}{|c|}{ Age (1 to 35 days) } \\
\hline \multirow{2}{*}{$\begin{array}{l}\text { Average feed } \\
\text { intake - AFI (g) }\end{array}$} & Mash & $2,947 \mathrm{Aa}$ & $2,936 \mathrm{Aa}$ & $2,922 \mathrm{Aa}$ & $2,911 \mathrm{Ba}$ & \multirow{2}{*}{0.033} & \multirow{2}{*}{0.443} & \multirow{2}{*}{0.001} & \multirow{2}{*}{0.005} \\
\hline & Pelleted & $3,014 \mathrm{Aa}$ & $2,984 \mathrm{Aa}$ & $3,051 \mathrm{Aa}$ & $3,114 \mathrm{Aa}$ & & & & \\
\hline \multirow{2}{*}{$\begin{array}{l}\text { Average weight } \\
\text { gain - AWG }(g)^{(2)}\end{array}$} & Mash & 1,998Aa & $2,027 \mathrm{Aa}$ & $2,052 \mathrm{Aa}$ & $2,059 \mathrm{Ba}$ & \multirow{2}{*}{0.019} & \multirow{2}{*}{0.001} & \multirow{2}{*}{0.001} & \multirow{2}{*}{0.031} \\
\hline & Pelleted & $2,078 \mathrm{Ab}$ & $2,072 \mathrm{Ab}$ & $2,102 \mathrm{Ab}$ & $2,182 \mathrm{Aa}$ & & & & \\
\hline \multirow{3}{*}{$\begin{array}{l}\text { Feed conversion } \\
\text { rate }-\mathrm{FCR}^{(3)}\end{array}$} & Mash & 1.476 & 1.448 & 1.424 & 1.414 & \multirow{2}{*}{0.012} & \multirow{2}{*}{0.002} & \multirow{2}{*}{0.792} & 0647 \\
\hline & Pelleted & 1.451 & 1.440 & 1.451 & 1.429 & & & & 0.016 \\
\hline & GMD & $1.458 \mathrm{~b}$ & $1.443 b$ & $1.422 \mathrm{a}$ & $1.416 \mathrm{a}$ & & & & \\
\hline
\end{tabular}


starch and protein (Behnke, 1994). Moreover, as pellets are disintegrated during digestion (Kheravii et al., 2018), SBM particle size in the pelleted diets may have contributed to the higher AWG results, particularly during the period of 1 to 35 days of age. The rate of coarse feed particles through the gastrointestinal tract can also be slower than that of fine particles, allowing a longer contact of the dietary nutrients with digestive enzymes and intestinal villi, which consequently enhances their digestion and absorption (Zaefarian et al., 2016; Siegert et al., 2018).

The effects of SBM particle size observed in the present study are consistent with the findings of Pacheco et al. (2013), who verified that 14- to 35-dayold birds fed diets with coarse SBM particles of 971 and $1,080 \mu \mathrm{m}$ presented a higher AWG and a better FCR than those fed finer SBM particles of 465 and $352 \mu \mathrm{m}$. Kilburn \& Edwards (2004) also reported higher digestion and absorption efficiencies when 1- to 16-day-old broilers were fed coarse SBM particles of $1,239 \mu \mathrm{m}$, compared with fine particles of $891 \mu \mathrm{m}$.

Throughout the entire experimental period, there was no influence of diet physical form on FCR ( $p>0.05$ ). However, the 1,406 and 1,053 $\mu \mathrm{m}$ SBM particle sizes led to the best results for FCR in broilers fed both the pelleted and the mash diets. Through the orthogonal contrasts, it was possible to observe a linear effect for AWG and FCR from 1 to 35 days of age $(p<0.05)$; however, AFI and other variables were not affected in the initial period. Both AWG and FCR improved linearly with increasing SBM particle sizes, which is in agreement with Pacheco et al. (2013), who observed similar effects when assessing different SBM particle sizes in mashed diets. In the present study, the combination of pelleted diets with coarser particles promoted the best results for the evaluated growth performance variables.

\section{Conclusions}

1. The particle size of soybean (Glycine max) meal, both in mash and pelleted diets, influences Cobb500 broilerperformance, as shown by the linearimprovement in average weight gain and feed conversion ratio with increasing soybean meal particle sizes.

2. The highest weight gain of 1- to 35-day-old Cobb500 broilers is achieved with the pelleted diet with $1,406 \mu \mathrm{m}$ soybean meal particle size.

\section{Acknowledgment}

To Conselho Nacional de Desenvolvimento Científico e Tecnológico (CNPq), for financial support (process number 1600597).

\section{References}

ABDOLLAHI, M.R.; RAVINDRAN, V.; WESTER, T.J.; RAVINDRAN, G.; THOMAS, D.V. Influence of feed form and conditioning temperature on performance, apparent metabolisable energy and ileal digestibility of starch and nitrogen in broiler starters fed wheat-based diet. Animal Feed Science and Technology, v.168, p.88-99, 2011. DOI: https://doi.org/10.1016/j. anifeedsci.2011.03.014.

AMERAH, A.M.; GILBERT, C.; SIMMINS, P.H.; RAVINDRAN, $\mathrm{V}$. Influence of feed processing on the efficacy of exogenous enzymes in broiler diets. World's Poultry Science Journal, v.67, p.29-46, 2011. DOI: https://doi.org/10.1017/S0043933911000031.

BEHNKE, K.C. Factors affecting pellet quality. In: MARYLAND NUTRITION CONFERENCE, 1994, Maryland. Proceedings. Maryland: University of Maryland, [1994]. p.44-54.

CHEWNING, C.G.; STARK, C.R.; BRAKE, J. Effects of particle size and feed form on broiler performance. Journal of Applied Poultry Research, v.21, p.830-837, 2012. DOI: https://doi.org/10.3382/japr.2012-00553.

COBB-VANTRESS. Cobb500: Broiler Performance \& Nutrition Supplement. [S.1.], 2013.14p.

DALMÉDICO, G.; ZANOTTO, D.L.; KRABBE, E.L.; COLDEBELLA, A. Granucalc: manual do usuário. Concórdia: Embrapa Suínos e Aves, 2013. 13p. (Embrapa Suínos e Aves. Documentos, 159).

DUARTE, K.F.; JUNQUEIRA, O.M. Aminoácidos sintéticos e enzimas: ferramentas importantes na redução dos custos de produção de frangos de corte. Revista Produção Animal, Avicultura, ed.73, p.22-23, 2013.

FÉLIX, A.P.; BRITO, C.B.M. de; FERRARINI, H.; RODRIGUES, M.I.G.; OLIVEIRA, S.G. de; MAIORKA, A. Características físico-químicas de derivados proteicos de soja em dietas extrusadas para cães. Ciência Rural, v.40, p.2568-2573, 2010. DOI: https://doi.org/10.1590/S0103-84782010001200021.

JACOBS, C.M.; UTTERBACK, P.L.; PARSONS, C.M. Effects of corn particle size on growth performance and nutrient utilization in young chicks. Poultry Science, v.89, p.539-544, 2010. DOI: https://doi.org/10.3382/ps.2009-00434.

KHERAVII, S.K.; MORGAN, N.K.; SWICK, R.A.; CHOCT, M.; WU, S.-B. Roles of dietary fibre and ingredient particle size in broiler nutrition. World's Poultry Science Journal, v.74, p.301316, 2018. DOI: https://doi.org/10.1017/S0043933918000259.

KHERAVII, S.K.; SWICK, R.A.; CHOCT, M.; WU, S.-B. Coarse particle inclusion and lignocellulose-rich fiber addition in feed benefit performance and health of broiler chickens. Poultry Science, v.96, p.3272-3281, 2017. DOI: https://doi.org/10.3382/ps/ pex123. 
KILBURN, J.; EDWARDS JR., H.M. The effect of particle size of commercial soybean meal on performance and nutrient utilization of broiler chicks. Poultry Science, v.83, p.428-432, 2004. DOI: https://doi.org/10.1093/ps/83.3.428.

LÓPEZ, C.A.A.; BAIÃO, N.C. Efeitos da moagem dos ingredientes e da forma física da ração sobre o desempenho de frangos de corte. Arquivo Brasileiro de Medicina Veterinária e Zootecnia, v.54, p.189-195, 2002. DOI: https://doi.org/10.1590/ S0102-09352002000200010.

LV, M.; YAN, L.; WANG, Z.; AN, S.; WU, M.; LV, Z. Effects of feed form and feed particle size on growth performance, carcass characteristics and digestive tract development of broilers. Animal Nutrition, v.1, p.252-256, 2015. DOI: https://doi.org/10.1016/j. aninu.2015.06.001.

MASSUQUETTO, A.; DURAU, J.F.; BARRILLI, L.N.E.; SANTOS, R.O.F. dos; KRABBE, E.L.; MAIORKA, A. Thermal processing of corn and physical form of broiler diets. Poultry Science, v.99, p.3188-3195, 2020. DOI: https://doi.org/10.1016/j. psj.2020.01.027.

MASSUQUETTO, A.; PANISSON, J.C.; MARX, F.O.; SUREK, D.; KRABBE, E.L.; MAIORKA, A. Effect of pelleting and different feeding programs on growth performance, carcass yield, and nutrient digestibility in broiler chickens. Poultry Science, v.98, p.5497-5503, 2019. DOI: https://doi.org/10.3382/ps/pez176.

MCKINNEY, L.J.; TEETER, R.G. Predicting effective caloric value of nonnutritive factors: I. Pellet quality and II. Prediction of consequential formulation dead zones. Poultry Science, v.83, p.1165-1174, 2004. DOI: https://doi.org/10.1093/ps/83.7.1065.

MORAN JR., E.T. Comparative nutrition of the fowl and swine: the gastrointestinal systems. Guelph: University of Guelph, 1982. p.185-198.

NADERINEJAD, S.; ZAEFARIAN, F.; ABDOLLAHI, M.R.; HASSANABADI, A.; KERMANSHAHI, H.; RAVINDRAN, $\mathrm{V}$. Influence of feed form and particle size on performance, nutrient utilisation, and gastrointestinal tract development and morphometry in broiler starters fed maize-based diets. Animal Feed Science and Technology, v.215, p.92-104, 2016. DOI: https://doi.org/10.1016/j.anifeedsci.2016.02.012.

OLIVEIRA, C.W. de; REIS, T.L.; MENDONÇA, L.V.P.; LIMA FILHO, M. Farinhas de insetos na avicultura industrial.
Brazilian Journal of Development, v.6, p.722-728, 2020. DOI: https://doi.org/10.34117/bjdv6n1-049.

PACHECO, W.J.; STARK, C.R.; FERKET, P.R.; BRAKE, J. Evaluation of soybean meal source and particle size on broiler performance, nutrient digestibility, and gizzard development. Poultry Science, v.92, p.2914-2922, 2013. DOI: https://doi.org/10.3382/ps.2013-03186.

ROSTAGNO, H.S. (Ed.). Tabelas Brasileiras para aves e suínos: composição de alimentos e exigências nutricionais. 3.ed. Viçosa: Universidade Federal de Viçosa, 2011.

SANTOS, R.O.F. dos; BASSI, L.S.; SCHRAMM, V.G.; ROCHA, C. da; DAHLKE, F.; KRABBE, E.L.; MAIORKA, A. Effect of conditioning temperature and retention time on pellet quality, ileal digestibility, and growth performance of broiler chickens. Livestock Science, v.240, 104110, 2020. DOI: https://doi.org/10.1016/j.livsci.2020.104110.

SHABANI, S.; SEIDAVI, A.; ASADPOUR, L.; CORAZZIN, M. Effects of physical form of diet and intensity and duration of feed restriction on the growth performance, blood variables, microbial flora, immunity, and carcass and organ characteristics of broiler chickens. Livestock Science, v.180, p.150-157, 2015. DOI: https://doi.org/10.1016/j.livsci.2015.07.006.

SIEGERT, W.; GANZER, C.; KLUTH, H.; RODEHUTSCORD, M. Effect of particle size distribution of maize and soybean meal on the precaecal amino acid digestibility in broiler chickens. British Poultry Science, v.59, p.68-75, 2018. DOI: https://doi.org/10.1080/00071668.2017.1380295.

TEIXEIRA NETTO, M.V.; MASSUQUETTO, A.; KRABBE, E.L.; SUREK, D.; OLIVEIRA, S.G.; MAIORKA, A. Effect of conditioning temperature on pellet quality, diet digestibility, and broiler performance. Journal of Applied Poultry Research, v.28, p.963-973, 2019. DOI: https://doi.org/10.3382/japr/pfz056.

ZAEFARIAN, F.; ABDOLLAHI, M.R.; RAVINDRAN, V. Particle size and feed form in broiler diets: impact on gastrointestinal tract development and gut health. World's Poultry Science Journal, v.72, p.277-290, 2016. DOI: https://doi.org/10.1017/S0043933916000222.

ZANOTTO, D.L.; BELLAVER, C. Método de determinação da granulometria de ingredientes para uso em rações de suínos e aves. Concórdia: Embrapa-CNPSA, 1996. 5p. (Embrapa-CNPSA. Comunicado técnico, 215). 